\title{
Mengenal Nyeri Neuropatik Akut Pasca Seksio Sesarea
}

\author{
Muh. Ramli Ahmad, Rezki Hardiyanti \\ Departemen Anestesiologi,Terapi Intensif \& Manajemen Nyeri \\ Fakultas Kedokteran Universitas Hasanuddin-RSUP Dr. Wahidin Sudirohusodo Makassar
}

\begin{abstract}
Abstrak
Nyeri neuropatik akut pascabedah Seksio Sesarea (SS) ditandai dengan adanya tanda dan gejala nyeri neuropatik yang berbeda dari nyeri nosiseptif berupa alodinia dan hiperalgesia, yang ditemukan pada periode awal hingga 1 bulan pascabedah. Nyeri neuropatik akut dapat terjadi akibat cedera langsung pada saraf iliohipogastrika dan ilionguinal akibat pembedahan SS, yang selanjutnya memicu pelepasan ektopik dan perubahan kanal ion pada saraf perifer, serta memicu terjadinya sensitisasi sentral. Meskipun demikian, disfungsi saraf pascabedah biasanya merupakan kombinasi dengan nyeri nosiseptif akibat kerusakan jaringan dan peradangan. Skrining perioperatif dan faktor risiko dapat menggunakan alat skrining Douleur Neuropathique en 4 (DN4) atau DN2 untuk mencegah perkembangan menjadi nyeri persisten. Pendekatan saat ini untuk pencegahan nyeri neuropatik kronis bertujuan untuk mengoptimalkan analgesia dan mengurangi nosisepsi dari nyeri akut dengan memodifikasi teknik bedah dan memilih anestesi regional. Pengobatan nyeri neuropatik memerlukan kombinasi terapi farmakologis, fisik, dan terapi perilaku. Beberapa terapi lini pertama pada penanganan nyeri neuropati akut seperti gabapentinoid, opioid, antagonis reseptor NMDA, hingga terapi stimulasi listrik transkutan dan stimulasi medula spinalis menjadi pertimbangan untuk nyeri neuropatik akut.
\end{abstract}

Kata kunci: Douleur Neuropathique en 4 (DN4), Nyeri neuropatik akut pascabedah, seksio sesarea, sensitisasi sentral

\section{Recognizing Acute Neuropathic Pain After Cesarean Section}

\begin{abstract}
Acute neuropathic pain after cesarean section (CS) is characterized by the presence of signs and symptoms of neuropathic pain that are different from nociceptive pain, in the form of allodynia and hyperalgesia in the early postoperative period to one month after surgery. Acute neuropathic pain may result from direct injury to the iliohipogastric and ilionguinal nerves due to CS, which in turn triggers the ectopic release and ion channel changes in peripheral nerves, and triggers the central sensitization. However, postoperative nerve dysfunction usually occur in combination with nociceptive pain due to tissue damage and inflammation. Perioperative and risk factors screening with the Douleur Neuropathique en 4 (DN4) or DN2 screening tool can prevent the progression into persistent pain. Thus, current approaches to prevent chronic neuropathic pain aimed to optimize analgesia and reduce nociception from acute pain by modification of surgical techniques and preference of regional anesthesia. Management of neuropathic pain may require a combination of pharmacological, physical, and behavioral therapy. Several first-line therapies in the management of acute neuropathic pain including gabapentinoid, opioids, NMDA receptor antagonists, up to transcutaneous electrical stimulation therapy and spinal cord stimulation may be considered for acute neuropathic pain.
\end{abstract}

Key words: Cesarean section, Central sensitization, Douleur Neuropathique en 4 (DN4), Postoperative acute neuropathic pain. 


\section{Pendahuluan}

Nyeri neuropatik didefinisikan oleh International Association for the Study of Pain (IASP) sebagai nyeri yang dimulai atau disebabkan oleh lesi primer atau disfungsi pada sistem saraf. ${ }^{1} \mathrm{Hal}$ ini sering dianggap sebagai kondisi nyeri kronis dan jarang ditemui sebagai masalah pada periode pascabedah. Namun, saat ini dikenal istilah acute neuropathic pain (ANP) yang nyatanya dapat menjadi penyebab nyeri pascabedah termasuk pasca Seksio Sesarea (SS). Meskipun demikian, disfungsi saraf pascabedah biasanya tidak terjadi secara tunggal tetapi merupakan kombinasi dengan nyeri nosiseptif akibat kerusakan jaringan dan peradangan. ${ }^{1}$ Nyeri pascabedah dianggap berasal dari nyeri nosiseptif dan jarang dipertimbangkan adanya kemungkinan keterlibatan nyeri neuropatik, termasuk pasca SS. Akibatnya, nyeri neuropatik akut sering tidak terdiagnosis dan oleh karena itu tidak diobati. ${ }^{2}$

Banyak penelitian telah dilakukan mengenai kejadian nyeri persisten setelah SS seperti pada banyak pembedahan lainnya, dengan kisaran nilai yang luas dari $<1 \%-23 \%$ yang terjadi hingga 12 bulan setelah SS.3 Sebuah penelitian prospektif terhadap 260 wanita sehat yang menjalani SS elektif di Swedia melaporkan kejadian wanita yang menderita nyeri persisten pada satu atau lebih lokasi menjadi $40 \%, 27 \%$ dan $22 \%$ pada tiga, enam dan 12 bulan setelah SS. ${ }^{4}$ Melihat data ini, tidak menutup kemungkinan nyerinya diawali oleh nyeri neuropatik akut namun tidak terdeteksi atau terabaikan karena nyeri persisten biasa didahului nyeri neuropatik akut yang tidak diterapi. Pendekatan mekanistik untuk mengklasifikasikan nyeri menjadi sangat penting, karena terdapat perbedaan dalam pendekatan penanganan neuropatik dibandingkan nyeri nosiseptif. $^{2}$

\section{Definisi}

Nyeri neuropatik didefinisikan sebagai "nyeri yang disebabkan oleh cedera atau penyakit pada sistem saraf somatosensorik". Nyeri neuropatik akut pascabedah ditandai dengan adanya tanda dan gejala nyeri neuropatik yang berbeda dari nyeri nosiseptif, berupa munculnya kesemutan, panas seperti terbakar, alodinia, hiperalgesia, atau disestesia yang ditemukan pada periode awal pascabedah. ${ }^{1,5,6}$ Beberapa literatur menyimpulkan bahwa istilah akut digunakan untuk mendefinisikan nyeri neuropatik yang terjadi dalam 24 jam setelah cedera saraf hingga satu bulan setelah cedera tersebut. ANP yang tidak terdiagnosis dan tidak tertangani dapat berkembang menjadi nyeri persisten kronis pascabedah yang menyebabkan morbiditas. ${ }^{6}$

\section{Patomekanisme}

\section{Patogenesis Cedera Saraf Pascabedah}

Nyeri neuropatik akut dapat terjadi akibat cedera langsung pada saraf akibat pembedahan. Derajat cedera saraf akan tergantung pada apakah yang terjadi adalah neuropraksia, aksonotmesis atau neurotmesis. ${ }^{1}$ Pada neuropraksia, akson tetap utuh, tetapi terdapat gangguan konduksi potensial aksi melalui saraf karena demielinisasi fokal atau disfungsi kanal ion. Pada aksonotmesis, terjadi pemutusan akson yang mengakibatkan degenerasi Wallerian distal. Bentuk cedera saraf yang paling parah adalah neurotmesis, di mana terdapat diskontinuitas keseluruhan saraf, termasuk epineurium dan jaringan ikat. ${ }^{2}$ Cedera saraf ini dapat disebabkan baik oleh efek anestesi, prosedur pembedahan, atau karena faktor lain seperti hipotensi, hipotermia dan tekanan pada saraf yang sakit saat pembedahan berlangsung. ${ }^{\text {? }}$ Nyeri neuropatik pasca SS dihubungkan dengan teknik insisi Pfannenstiel pada pembedahan SS karena risiko hernia insisional yang lebih rendah dan manfaat estetika. Nyeri yang terusmenerus muncul setelah SS ditandai sebagai nyeri neuropatik dan dapat terjadi akibat cedera saraf ilioinguinal dan iliohipogastrik yang menyebabkan nyeri persisten. ${ }^{3}$

Cedera jaringan dan saraf adalah penyebab utama nyeri persisten. Dengan demikian, modifikasi potensial teknik pembedahan untuk mengurangi cedera jaringan, inflamasi atau respon adhesi, dan untuk mengurangi atau menghindari cedera atau jeratan saraf dapat membantu mengurangi risiko nyeri persisten. ${ }^{3}$ Sebuah penelitian menemukan bahwa eksteriorisasi uterus mengakibatkan 
frekuensi nyeri sedang atau berat yang lebih tinggi enam jam setelah pembedahan jika dibandingkan dengan perbaikan uterus in situ. ${ }^{8}$ Diseksi yang hati-hati dan lembut, teknik yang sedikit melibatkan otot, tidak menutup peritoneum, menghindari eksteriorisasi uterus, sayatan dan pembedahan yang lebih kecil, dan durasi yang lebih singkat harus dipertimbangkan untuk mengurangi nyeri yang menetap setelah SS. Modifikasi ini belum terbukti mengurangi nyeri persisten tetapi mengurangi nyeri akut pascabedah. $^{3}$

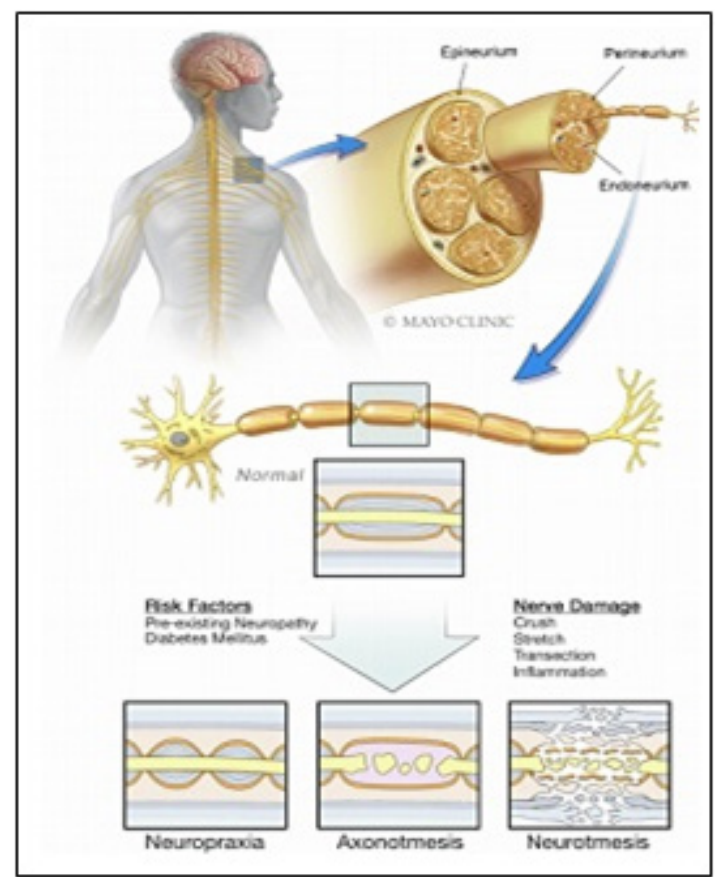

Gambar 1. Klasifikasi Cedera Saraf

(Dikutip dari : Laughlin RS et al. Postsurgical neuropathy: A descriptive review. Mayo Clin Proc. 2020;95(2):355-69)

Kerusakan saraf perifer mayor mungkin terlibat pada timbulnya nyeri neuropatik setelah pembedahan. Dugaan bahwa hiperalgesia sensorik yang muncul setelah artroplasti pinggul mungkin disebabkan oleh kerusakan otot atau jaringan dalam, didukung oleh eksperimen yang meneliti 'nyeri otot neuropatik' pada model hewan. Sebuah penelitian memberikan bukti eksperimental bahwa hiperalgesia otot yang persisten terjadi pada model hewan dengan nyeri neuropatik. Hal ini menunjukkan bahwa nyeri neuropatik yang timbul dari otot mungkin merupakan masalah klinis yang lebih besar daripada yang umumnya diketahui dan dapat berkontribusi pada perkembangan nyeri neuropatik setelah pembedahan. ${ }^{9}$ Dua proses yang saling bergantung tampaknya menjadi kontributor utama untuk berkembangnya nyeri neuropatik akut akibat kerusakan saraf pascabedah, yakni keseimbangan antara reaksi kompensasi dan dekompensasi sistem saraf sebagai respon terhadap kerusakan saraf dan latar belakang genetik yang meningkatkan atau melindungi seorang individu dari terjadinya nyeri neuropatik. Banyak perubahan yang terjadi sebagai respon terhadap cedera saraf berpotensi maladaptif seperti perubahan ambang batas dan sensitivitas saraf, pelepasan impuls ektopik, gangguan konduksi, konektivitas yang tidak tepat, pertumbuhan saraf yang gagal, degenerasi sel saraf, dan jaringan parut glial. Beberapa dari perubahan ini terjadi lebih awal setelah kerusakan saraf dan berpartisipasi dalam fase induksi nyeri neuropatik. ${ }^{10}$

\section{Pelepasan Ektopik dan Perubahan Kanal ion pada Akson Neuron Sensorik}

Pada kondisi fisiologis, aktivasi serabut saraf nosiseptif tidak bermielin (serat C) dan yang bermielin tipis (serat $\mathrm{A} \delta$ ) menunjukkan potensi kerusakan jaringan baik oleh rangsangan mekanis, termal, maupun kimiawi. Kondisi ini berubah secara dramatis pada keadaan nyeri neuropatik. Setelah lesi saraf tepi, aktivitas spontan terbukti dapat terjadi pada serabut aferen nosiseptif yang cedera maupun yang tidak cedera. Peningkatan mRNA pada kanal natrium bertegangan tampaknya berkorelasi dengan aktivitas ektopik dan peningkatan ekspresi kanal natrium pada serabut saraf yang mengalami cedera dapat menurunkan ambang batas potensial aksi sampai aktivitas ektopik berlangsung. Perubahan serupa pada neuron nosiseptif kedua diperkirakan terjadi setelah lesi sentral, yang menyebabkan timbulnya nyeri neuropatik sentral. ${ }^{11}$

Selain itu, Beberapa penelitian berhasil membuktikan bahwa ekspresi subtipe kanal natrium (misalnya, Nav1.3, Nav1.7, Nav1.8, dan Nav1.9) secara dramatis berubah karena adanya cedera saraf dan dapat menjelaskan peningkatan 
rangsangan neuron dorsal root ganglia (DRG) setelah cedera saraf perifer. Penelitian terbaru menunjukkan bahwa kemokin, seperti growthrelated oncogene (GRO) dalam DRG memainkan peran penting dalam perubahan ekspresi kanal natrium yang diinduksi cedera saraf. ${ }^{12,13}$

Penurunan kepadatan kanal kalium setelah aksotomi dapat juga meningkatkan rangsangan neuron sensorik. Hal ini didukung oleh penelitian bahwa meksiletin dapat menyebabkan redaman nyeri neuropatik, juga memfasilitasi arus $\mathrm{K}+$ pada neuron DRG. Penelitian sebelumnya juga menunjukkan bahwa cedera saraf tepi menimbulkan perubahan kanal $\mathrm{Ca} 2+$ yang peka rangsangan pada neuron DRG. Sejak kanal tersebut terlibat dalam mengontrol pelepasan neurotransmiter dari terminal neuron sensorik, sentral dan simpatis di sumsum tulang belakang, perubahan ini memberi implikasi yang signifikan pada pemrosesan nosiseptif dalam kondisi patologis. Faktanya, kemampuan antikonvulsan (misalnya, karbamazepin dan gabapentin) untuk mengurangi alodinia mekanis dapat melibatkan mekanisme interaksi dengan kanal $\mathrm{Ca} 2+$ yang terlokalisasi pada neuron DRG yang cedera. ${ }^{12,13}$

\section{Sensitisasi Sentral}

Patofisiologi nyeri pascabedah termasuk pada SS bersifat kompleks dan mencakup elemen nosiseptif (yang dihasilkan oleh stimulus berbahaya dari pembedahan), dan inflamasi (akibat cedera jaringan dan aktivasi sel imun). ${ }^{6}$ Adapun nyeri neuropatik akut pascabedah terjadi akibat perubahan baik pada sistem saraf tepi maupun sistem saraf pusat. Pada sistem saraf tepi terjadi peningkatan pelepasan neurotransmiter yang mengurangi ambang batas nosiseptor., ${ }^{4,5}$ Oleh karena itu, terjadi peningkatan masukan aferen melalui serabut nyeri A $\delta$ dan $C$. Terdapat pula pelepasan ektopik dari kanal ion $\mathrm{Na}+$ dan kanal ion lainnya, misalnya reseptor adrenergik. Sedangkan pada sistem saraf pusat khususnya pada area kornu dorsalis medula spinalis, perubahan pelepasan neurotransmiter, aktivitas neuronal, kejadian intraseluler (ekspresi gen) dan perubahan anatomis dapat terjadi dengan sangat cepat. Glutamat adalah neurotransmiter yang dianggap penting pada terjadinya nyeri neuropatik. Ketika reseptor N-methyl-D-aspartate (NMDA) teraktivasi, glutamat dengan cepat akan terikat pada reseptor tersebut dan selanjutnya meningkatkan $\mathrm{Na}+$ dan $\mathrm{Ca} 2+$ intraseluler. Proses ini selanjutnya memicu aktivasi protein kinase $\mathrm{C}$, fosfolipase $\mathrm{C}, \mathrm{NO}$ sintase dan juga dengan segera menginduksi ekspresi gen. Terdapat juga impuls yang timbul dari serabut A dan biasanya bersinaps dengan lamina IV/V yang kemudian berhubungan dengan lamina II (substantia gelatinosa). Hal ini menjelaskan alodinia dan hiperalgesia. ${ }^{4}$

Pada tingkat sentral, sensitisasi berkembang sebagai akibat aktivitas ektopik di perifer. Hal ini menyebabkan peningkatan pelepasan rangsang asam amino (misalnya, glutamat yang bertanggung jawab untuk peningkatan aktivasi NMDA yang menyebabkan eksitabilitas neuronal) dan neuropeptida (misalnya, substansi P) di kornu dorsalis sumsum tulang belakang, kemudian menyebabkan perubahan fungsional neuron kedua. Perubahan ini disebut sebagai neuroplastisitas dan bermanifestasi sebagai hipereksitabilitas yang menyebabkan hiperalgesia dan alodinia. Perubahan serupa juga terjadi pada tingkat supraspinal. ${ }^{2}$

Proses sensitisasi sentral sangat bergantung pada fosforilasi reseptor NMDA yang diaktifkan glutamat. Pada keadaan fisiologis, kanal NMDA tetap diam karena inhibisi oleh magnesium $(\mathrm{Mg})$. Namun membran sel saraf akan mengalami depolarisasi progresif sebagai respon terhadap stimulasi berulang melalui aktivasi reseptor $\alpha$-amino-3-hydroxy5-methyl-4-isoxazolepropionic acid (AMPA) oleh glutamat dan neurokinin 1 (NK1) oleh substansi $\mathrm{P}$, blokade $\mathrm{Mg}$ dihilangkan, dan glutamat mampu mengaktifkan reseptor. Sebagai respon terhadap kondisi ini, terjadi aliran masuk $\mathrm{Ca} 2+$ yang mengaktifkan kanal ion $\mathrm{Ca} 2+$ dan enzim fosforilasi, termasuk protein kinase A (PKA) dan C (PKC) serta protein kinase yang diaktifkan mitogen (mitogen-activated protein kinase, MAPK). Jadi, eksitasi input aferen yang berkolateral dengan segmen distal tidak cukup menyebabkan neuron tereksitasi, tetapi sekali neuron pada segmen distal menjadi peka setelah cedera, stimulus biasa cukup untuk mengeksitasi 
neuron segmentalyang jauh, dikenal dengan istilah "wind-up". ${ }^{12}$ Secara khusus, PKC mengaktifkan reseptor NMDA dan kanal $\mathrm{Na}+$, menyebabkan depolarisasi lebih lanjut yang berkontribusi pada wind-up. MAPK P38 memfosforilasi enzim, termasuk fosfolipase A2, yang memulai pelepasan asam arakidonat dan menyediakan substrat untuk jalur cyclooxygenase (COX) mensintesis prostaglandin (PGE). PGE bekerja prasinaptik dan pascasinaptik untuk meningkatkan pembukaan kanal ion $\mathrm{Ca} 2+$ untuk memblokir penghambatan glisinergik di tingkat interneuron. Aktivasi input aferen dan neuron kedua diatur oleh inhibisi lokal interneuron yang melepaskan asam amino inhibisi, termasuk GABA dan glisin. Ketika input aferen frekuensi tinggi terjadi, penghambatan berkurang yang menyebabkan peningkatan respons neuron wide dynamic range (WDR). Hilangnya penghambatan melalui GABA atau input glisin menambah respon neuron WDR yang memfasilitasi rangsangan pada kornu dorsal. ${ }^{12}$

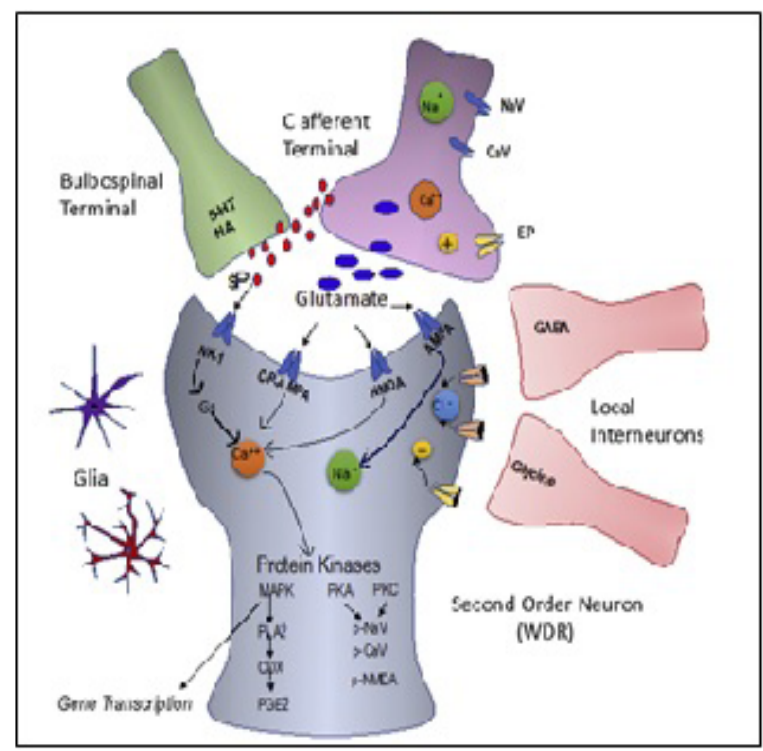

Gambar 2. Sensitisasi sentral: eksitasi aferen primer menghasilkan glutamat dan pelepasan substansi $\mathbf{P}$, yang bekerja secara sinapsis pada neuron kedua dan eksitasi meningkatkan kalsium intraseluler dan mengaktifkan segudang protein kinase.

(Dikutip dari: Fisher CJ, Yaksh TL, Bruno K, Eddinger KA. Basic Science of Pain: In Pangarkar S, Pham QG, Eapen BC, eds. Pain Care Essentials and Innovations. Cathleen Sether Publisher. 2020. p. 1-13.)

\section{Faktor Risiko}

Identifikasi faktor risiko terjadinya nyeri persisten setelah SS dapat membantu mencegah atau memprediksi kondisi transisi neuropatik ke persisten. ${ }^{3}$

\section{Faktor Risiko Prabedah}

Faktor risiko prabedah penting untuk dikenali pada pasien yang mungkin cenderung mengalami nyeri persisten setelah SS.3 Sebuah penelitian menjelaskan bahwa jika alasan dilakukannya SS adalah psikologis (didefinisikan sebagai SS atas permintaan ibu), terdapat risiko yang jauh lebih tinggi untuk nyeri kronis pada periode waktu tiga bulan, sementara SS darurat juga dikaitkan dengan peningkatan nyeri persisten. Hal ini telah dibuktikan secara eksperimental bahwa stres sebelum atau sesudah pembedahan memperpanjangdurasihiperalgesiayang diinduksi oleh insisi. Berbagai faktor psikososial mungkin memainkan peran penting dan memerlukan penyelidikan lebih lanjut, meskipun temuan dari penelitian sebelumnya tidak selalu konsisten atau konklusif. ${ }^{4}$ Nyeri yang ada sebelum kehamilan atau selama kehamilan dapat merupakan faktor risiko terjadinya nyeri persisten. Kecenderungan nyeri persisten pada pasien dengan nyeri atau cedera atau pembedahan sebelumnya sesuai dengan konsep disekuilibrium, dengan hilangnya keseimbangan dari keadaan alostatik kompensasi sistem antinosiseptif dari rasa sakit atau cedera yang sudah ada sebelumnya. ${ }^{3}$ Seiring dengan nyeri yang sudah ada sebelumnya, data klinis dan eksperimental mendukung hiperalgesia yang diinduksi opioid, yang mengaitkan paparan opioid prabedah dan perioperatif dengan peningkatan nyeri persisten setelah pembedahan. Hal ini ditunjukkan pada model tikus bahwa opioid dapat menyebabkan hiperalgesia yang berlebihan, sementara dosis opioid berulang mengakibatkan sensitisasi sentral yang persisten yang dapat dicegah dengan antagonis reseptor NMDA, seperti ketamin. ${ }^{3}$

\section{Faktor Risiko Intraoperatif}

Identifikasi faktor risiko intraoperatif dapat membantu memahami komponen pembedahan yang dapat ditargetkan untuk mengurangi 
kejadian nyeri persisten setelahnya. Dalam sebuah penelitian terhadap 866 wanita Belanda, adanya lebih dari dua sayatan Pfannenstiel dan SS darurat merupakan faktor risiko yang signifikan terjadinya nyeri persisten. Ditunjukkan bahwa peningkatan ukuran dan/atau jumlah sayatan Pfannenstiel dapat mengakibatkan kerusakan atau terperangkapnya saraf yang menginervasi area suprapubik dan perut bagian bawah serta pembentukan neuroma, yang berkontribusi pada terjadinya nyeri neuropatik. ${ }^{3}$ Jenis anestesi yang digunakan untuk SS telah diteliti sebagai salah satu cara yang berpotensial mencegah nyeri persisten.

Anestesi regional dan neuraksial terbukti lebih unggul dari anestesi umum dalam mengurangi nyeri persisten setelah SS. Blok saraf dapat bekerja dengan menghambat transmisi nyeri inflamasi dan nosiseptif dari perifer ke sistem saraf pusat, yang dengan demikian menghambat mekanisme terjadinya sen- sitisasi pusat. Hal ini mengurangi kebutuhan opioid selama pembedahan dan dapat menurunkan hiperalgesia yang diinduksi opioid. ${ }^{3}$ Pada sebuah ulasan Cochrane, didapatkan bahwa data yang dikumpulkan dari empat penelitian acak terkontrol dengan total 551 pasien menyukai anestesi regional/ neuraksial daripada anestesi umum untuk risiko nyeri persisten yang lebih rendah 3-8 bulan setelah SS. ${ }^{14}$

\section{Faktor Pascabedah}

Banyak bukti yang mendukung derajat keparahan nyeri pascabedah akut yang tinggi sebagai faktor risiko yang terkait dengan transisi nyeri akut menjadi nyeri kronis. Penelitian awal menunjukkan pasien yang melaporkan nyeri persisten setelah SS lebih mungkin mengalami nyeri pascabedah akut yang berat dibandingkan dengan mereka yang tidak nyeri persisten $(66 \%$ vs $44 \%){ }^{3}$ Penelitian prospektif terhadap 857 pasien yang menjalani SS elektif dengan anestesi spinal dan morfin intravena dengan Patient Controlled Analgesia (PCA) selama 24 jam pertama pascabedah. Mereka menemukan bahwa skor nyeri lebih tinggi pada periode 24 jam pascabedah merupakan faktor risiko terjadinya nyeri kronis. ${ }^{15}$

\section{Skrining Nyeri Perioperatif}

Intensitas nyeri dapat dievaluasi menggunakan beberapa modalitas, salah satunya yang cukup sederhana adalah Numerical Rating Scale (NRS) ${ }^{6,16}$ Selain NRS, untuk mendiagnosis nyeri neuropatik dapat digunakan kuesioner DN4. Kuesioner DN4 mengevaluasi 10 poin mengenai karakteristik nyeri, yang meliputi: (1) sensasi terbakar, (2) nyeri termal, (3) sensasi sengatan listrik, (4) kesemutan, (5) sensasi tusukan jarum, (6) mati rasa, (7) gatal, (8) nyeri lokal, (9) hipostesia terhadap sentuhan ataupun tusukan, dan (10) nyeri yang disebabkan atau meningkat akibat gesekan di daerah yang sakit. Poin 1-7 dari kuesioner DN4 diisi berdasarkan jawaban pada wawancara pasien, sedangkan poin $8-10$ membutuhkan pemeriksaan pasien. Skor DN4 adalah jumlah total dari 10 poin ini yang ada pada setiap pasien dan nilai cut off untuk diagnosis nyeri neuropatik adalah skor $4 / 10$. Untuk mengetahui apakah nyeri neuropatik ini berlangsung secara akut, penilaian dengan kuisoner DN4 atau DN2 dilakukan sebelum pembedahan dan pada hari 1 dan 6 sesudah pembedahan, sementara untuk mengevaluasi apakah nyeri berlangsung secara kronik dilakukan penilaian pada bulan 3, 6, dan 12 setelah pembedahan. ${ }^{17}$ Penelitian lain juga menilai ANP dengan kuesioner DN4, di mana nyeri dievaluasi sebelum pembedahan dan setidaknya 2 jam setelah pembedahan dan pada hari kedua pascabedah. ${ }^{18}$

\section{Penatalaksanaan}

Pengobatan nyeri neuropatik memerlukan kombinasi terapi farmakologis, fisik, dan terapi perilaku. Masih sangat sedikit bukti untuk pengobatan nyeri neuropatik akut, sehingga strategi manajemen pada keadaan akut harus didasarkan pada pengobatan berbasis bukti dari keadaan nyeri kronis. ${ }^{2,20}$ Karena kurangnya data spesifik, pedoman membuat rekomendasi umum berdasarkan pengalaman pada manajemen nyeri neuropatik kronis, sehingga disarankan untuk menggunakan antidepresan trisiklik, antikonvulan dan stabilisator membran dalam pengelolaan nyeri neuropatik akut. Ulasan terbaru lainnya juga menunjukkan bahwa penambahan tramadol 


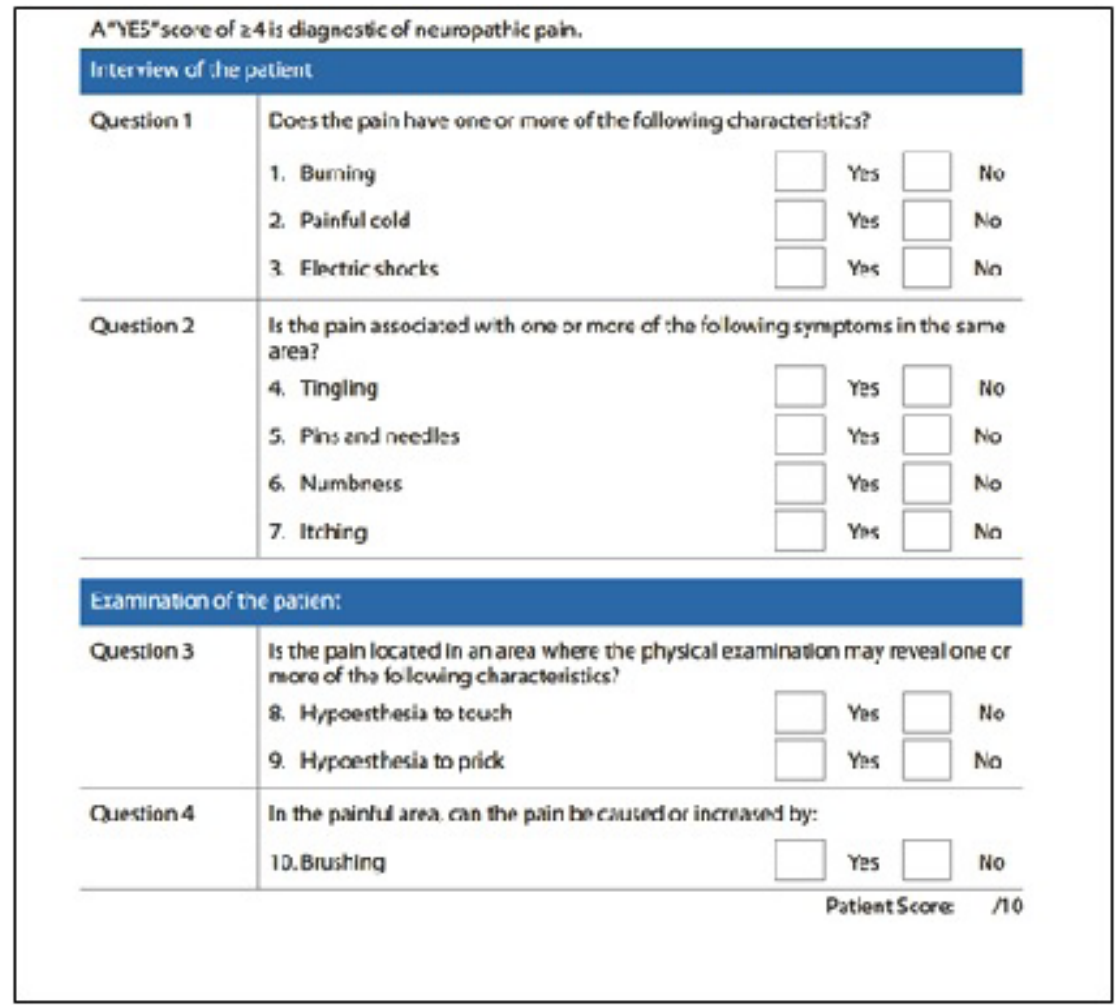

Gambar 5. Formulir Kuisoner $\mathbf{D N}^{4}$

(Dikutip dari: Artemiadis AK, Panagiotis Zis. Neuropathic Pain in Acute and Subacute Neuropathies: A Systematic Review. Pain Physician 2018; 21:111-20)

atau opioid lain dapat berguna untuk penanganan awal pada nyeri neuropatik akut. ${ }^{21}$

\section{Terapi Farmakologis}

\section{Antikonvulsan}

Gabapentin merupakan obat antikonvulsan yang memiliki komponen analgesia, khususnya nyeri neuropatik. Gabapentin telah diteliti secara luas dalam pengelolaan nyeri kronik dan untuk analgesia pascabedah, di mana obat ini dihubungkan dengan lebih banyaknya penghentian opioid. Akan tetapi, perannya pada pasien pasca SS yang belum mendapatkan opioid sebelumnya masih belum jelas. Sebagai bagian dari regimen obat analgesia, gabapentin oral $600 \mathrm{mg}$ yang diberikan sebelum pembedahan berhubungan dengan skor nyeri yang lebih rendah pada saat bergerak maupun istirahat. Akan tetapi, insidens sedasi lebih tinggi pada kelompok gabapentin dibandingkan pada kelompok plasebo. ${ }^{22}$ Pada sebuah penelitian tindak lanjut, dibandingkan pemberian gabapentin $300 \mathrm{mg}$ dan $600 \mathrm{mg}$ dengan plasebo dengan harapan untuk menemukan dosis yang efektif dengan sedasi yang lebih rendah. Sayangnya, penelitian tersebut gagal menunjukkan efikasi gabapentin pada kedua dosis. Gabapentin dapat memiliki peran dalam analgesia pasca SS pada pasien dengan nyeri kronik dan pasien dengan toleransi opioid. Penelitian lain menemukan bahwa dosis gabapentin $900 \mathrm{mg}$ lebih efektif daripada 600 mg dalam mengurangi nyeri pasca SS, konsumsi opioid, mual, dan muntah. Sedangkan sebuah ulasan sistematik dan meta-analisis menunjukkan bahwa penggunaan profilaksis gabapentin oral $600 \mathrm{mg}$ sebelum SS meningkatkan kontrol nyeri pascabedah pada pasien sehat (ASA I atau II) yang menjalani anestesi spinal dengan opioid intratekal, sama baiknya dengan yang mendapatkan OAINS dan asetaminofen pasca persalinan. ${ }^{22-24}$

Sebuah penelitian membandingkan antara gabapentin oral dengan pregabalin oral untuk 
mengurangi nyeri pascabedah pada pasien yang menjalani SS dengan anestesi spinal. Pada penelitian ini, pemberian pregabalin preemtiflebih efektif dibandingkan dengan gabapentin dalam mengurangi insentitas nyeri akut pascabedah dan mengurangi kebutuhan meperidin selama 24 jam pasca pembedahan tanpa efek samping serius. Berbeda dengan hasil penelitian tersebut, penelitian lain yang membandingkan pemberian pregabalin $300 \mathrm{mg}$ dan gabapentin $600 \mathrm{mg}$ dengan plasebo menyimpulkan bahwa pregabalin sama efektifnya dengan gabapentin tetapi lebih unggul daripada plasebo. ${ }^{25,26}$

Penelitian mengenai pemberian pregabalin 300 mg prabedah mengurangi konsumsi morfin dan nyeri akut pascabedah pada pasien SS dengan anestesi spinal. Akan tetapi, peneliti tidak yakin bahwa efek hemat morfin maternal menjustifikasi risiko peningkatan sedasi dan paparan bayi terhadap risiko pemberian pregabalin yang belum diketahui. Pada sebuah ulasan sistematis dengan meta-analisis dan analisis sekuensial penelitian mengenai manfaat dan bahaya pregabalin pada penatalaksanaan nyeri akut, disimpulkan bahwa berdasarkan beberapa penelitian dengan risiko bias yang rendah, pregabalin memiliki efek hemat opioid minimal, tetapi risiko efek samping serius tampaknya meningkat. Akan tetapi, evaluasi peringkat GRADE hanya menunjukkan bukti dengan kualitas menengah hingga sangat rendah. Akibatnya, penggunaan rutin pregabalin untuk penatalaksanaan nyeri pascabedah tidak dapat direkomendasikan. ${ }^{27,28}$

\section{Stabilisator Membran}

Lidokain memberi efek analgetik melalui blokade kanal natrium. Terdapat peningkatan ekspresi kanal natrium pada saraf perifer yang rusak dengan depolarisasi ektopik. Hanya terdapat sedikit bukti penggunaan agen ini pada pengobatan ANP. Sebuah studi kohort berskala kecil menunjukkan penurunan skor nyeri dibandingkan dengan basal dengan penggunaan lidokain intravena pada pasien dengan luka bakar parsial $10-30 \%{ }^{21}$

Pada fase akut, lidokain parenteral atau ketamin atau kombinasi keduanya dapat digunakan. Pada saat yang sama terapi oral harus dimulai dan dosis distabilkan selama 1-2 minggu. ${ }^{2}$ Sebuah penelitian acak terkontrol plasebo tersamar ganda menemukan bahwa bolus kecil $1,5 \mathrm{mg} / \mathrm{kg}$ lidokain intravena selama induksi anestesi umum untuk SS elektif menurunkan konsumsi morfin pascabedah selama 24 jam pertama setelah pembedahan. ${ }^{29}$

\section{Tramadol}

Tramadol dan opioid tetap direkomendasikan sebagai agen lini pertama karena onset timbulnya efek berlangsung cepat, meskipun nyeri neuropatik biasanya kurang responsif terhadap opioid dibandingkan nyeri nosiseptif. Berbagai penelitian masih menunjukkan responsivitas opioid pada sejumlah kondisi nyeri neuropatik. ${ }^{2}$ Perlu dihindari penggunaan kombinasi tramadol dengan antidepresan trisiklik atau selective serotonine reuptake inhibitor (SSRI) karena efek gabungannya dapat menurunkan ambang batas terjadinya kejang dan peningkatan risiko sindrom serotonin. ${ }^{21}$ Sebuah penelitian membandingkan pemberian kombinasi sufentanil-tramadol dengan dosis berbeda untuk mengurangi nyeri dalam 24 jam pertama pasca SS. Penelitian ini menunjukkan bahwa VAS nyeri pascabedah menurun seiring dengan peningkatan moderat konsentrasi sufentanil dan tramadol dalam 24 jam pascabedah. Selain itu, konsumsi total sufentanil berkurang, tanpa peningkatan insidens efek samping. Dengan menyesuaikan konsentrasi kombinasi sufentanil-tramadol, analgesia pascabedah dapat ditingkatkan. ${ }^{31}$

\section{Antagonis Reseptor NMDA}

Obat golongan antagonis reseptor NMDA, seperti ketamin pada dosis subanestetik efektif dalam mengurangi kebutuhan morfin dalam 24 jam pertama setelah pembedahan. Obat ini merupakan modulator sensitisasi sentral dan bermanfaat sebagai analgesik selain opioid (tramadol dan morfin) setelah pembedahan mayor pada abdomen dan telah terbukti berguna untuk mengobati nyeri neuropatik yang tidak responsif. Namun, efek analgesik jangka panjang dari antagonis NMDA belum terbukti memuaskan. ${ }^{31}$

Sebuah penelitian mempelajari efek ketamin 
intravena $10 \mathrm{mg}$ pada periode perioperatif. Meskipun tidak terdapat perbedaan dalamkejadian nyeri breakthrough dalam 24 jam pertama, penelitian menunjukkan bahwa mungkin ada manfaatnya dalam mengurangi nyeri dua minggu setelah SS. Efek psikomimetik ketamin dicatat dengan menggunakan kuesioner yang divalidasi: $35 \%$ pasien melaporkan pusing, kepala terasa ringan atau penglihatan kabur selama infus tetapi tidak ada efek permanen pascabedah. ${ }^{32}$

\section{Agen Topikal}

Lidokain, capsaicin, klonidin, amitriptilin, dan ketamin telah digunakan secara topikal dalam pengobatan nyeri neuropatik. Lidokain patch $5 \%$ telah menunjukkan pengurangan nyeri dan alodinia taktil dengan risiko efek samping sistemik minimal. ${ }^{20}$

\section{Blok Saraf Regional}

Berbagai blok regional dan simpatis telah digunakan dalam pengobatan nyeri neuropatik, namun sebagian besar intervensi ini tidak efektif atau hanya memberi efek jangka pendek. Terdapat rekomendasi lemah terhadap penggunaan anestesi lokal epidural atau paravertebra/blok steroid untuk pengobatan nyeri akut yang berhubungan dengan herpes zoster yang mungkin juga bersifat pencegahan terhadap neuralgia pascaherpetik, namun blok simpatis tidak dianjurkan. Demikian pula, terdapat rekomendasi yang lemah pada injeksi steroid epidural untuk mengobati radikulopati. Namun pada keadaan akut, bahkan efek durasi yang terbatas, blok saraf regional dapat bermanfaat, mirip dengan penggunaan terapi analgesik pada perawatan paliatif. Oleh karena itu, blok saraf regional, idealnya menggunakan infus melalui kateter, dipertimbangkan untuk pengobatan nyeri neuropatik akut lokal setelah pembedahan atau cedera. ${ }^{2}$ Opioid neuraksial juga memberikan analgesia pasca SS yang lebih unggul dibandingkan dengan teknik regional selain neuraksial seperti blok transversus abdominis plane (TAP), infiltrasi luka pembedahan, dan obat analgesia oral. Walaupun analgesia neuraksial menawarkan manfaat yang penting dalam mengoptimalkan analgesia pasca pembedahan, strategi analgesia multimodal meningkatkan efek analgesia opioid neuraksial. Meskipun analgesia yang dihasilkan lebih unggul, beberapa efek samping terkait opioid (mis. pruritus) lebih sering terjadi pada pemberian opioid neuraksial. ${ }^{22}$

\section{Stimulasi Listrik Saraf Transkutan}

Pemberian stimulasi listrik secara transkutan ke saraf menunjukkan efek yang berguna secara klinis untuk menghilangkan rasa sakit meskipun teknik ini bersifat sederhana dan tidak invasif. Namun, belum cukup data berbasis bukti untuk mendukung teknik ini sebagai alternatif pengobatan nyeri neuropatik. ${ }^{2}$

\section{Stimulasi Medula Spinalis}

Stimulasi medulla spinalis terbukti efektif pada kondisi nyeri neuropatik tertentu, yaitu nyeri lengan atau kaki setelah pembedahan lumbal atau serviks, nyeri neuropatik akibat kerusakan saraf perifer seperti sindrom nyeri regional kompleks (tipe 1) dan nyeri yang berhubungan dengan penyakit pembuluh darah perifer. Stimulasi medula spinalis mengurangi rasa sakit, meningkatkan kualitas hidup, mengurangi konsumsi analgesik dan memungkinkan beberapa pasien untuk kembali bekerja, dengan efek samping yang minimal. Hal ini dapat menghemat biaya. ${ }^{31}$

\section{Terapi Fisik dan Perilaku}

Terapi fisik pada manajemen nyeri neuropatik meliputi terapi panas dan dingin, diatermi gelombang pendek, transcutaneus electrical nerve stimulation[TENS], laser dan teknik neurostimulasi seperti stimulasi otak dalam dan stimulasi magnetik transkranial. Rehabilitasi juga merupakan bagian penting dari manajemen nyeri neuropatik. Tujuan utama rehabilitasi adalah untuk mengurangi rasa nyeri dan dosis farmakoterapi, meningkatkan disfungsi, meningkatkan kualitas hidup dan aktivitas fisik. Berbagai jenis latihan terapeutik telah digunakan dalam program rehabilitasi seperti latihan pengkondisian, penguatan, dan peregangan. Tujuan psikoterapi adalah untuk mengobati disfungsi emosional, perilaku, atau mental; menghilangkan gejala negatif seperti kecemasan atau depresi; memodifikasi atau membalikkan perilaku bermasalah; membantu individu mengatasi krisis situasional seperti 
kehilangan, rasa sakit, atau penyakit medis yang berkepanjangan. ${ }^{33}$

\section{Pertimbangan Maternal dan Fetal}

Analgesia yang baik mendorong keberhasilan pemberian ASI dan ikatan ibu dan bayi, tetapi obat analgesia berpotensi ditransferkan pada bayi yang menyusui. Paparan obat neonatus utamanya diekspresikan sebagai dosis infan relatif (RID). RID memperhitungkan berat badan ibu dan bayi dan RID lebih dari 10\% umumnya dianggap batas level yang harus diperhatikan. Tabel 1 menunjukkan RID obat analgesia yang umum digunakan untuk manajemen nyeri pasca SS. ${ }^{33}$ Obat analgesia pascabedah untuk wanita menyusui diberikan dengan mempertimbangkan beberapa prinsip umum berikut: ${ }^{33}$ 1) analgesia multimodal hemat opioid lebih dipilih, karena opioid berhubungan dengan transfer obat ke ASI dan dapat menyebabkan sedasi neonatus, 2) jumlah obat di dalam ASI paralel dengan kadar obat maternal. Sebaiknya digunakan dosis efektif terendah dan pemberian opioid intratekal atau epidural dibandingkan opioid intravena jika

Tabel 1. Potensi transfer ke ASI obat Analgesia yang sering Digunakan setelah SS

\begin{tabular}{ll}
\hline Obat Analgesia & Dosis Infan Relatif $(\%)$ \\
\hline Opioid & \\
Morfin & $5,8-10,7$ \\
Fentanyl & $0,9-3$ \\
Oksikodon & $1,5-8$ \\
Hidrokodon & $1,6-3,7$ \\
Tramadol & $2,4-2,9$ \\
Non-opioid & \\
Ibuprofen & $0,1-0,7$ \\
Ketorolak & $0,2-0,4$ \\
Celecoxib & 0,3 \\
Asetaminofen & $1,3-6,4$ \\
Deksametason & Tidak ada data \\
Gabapentin & $1,3-6,5$ \\
Pregabalin & Tidak ada data \\
\hline
\end{tabular}

Dikutip dari: Sutton CD, Carvalho B. Optimal pain management after cesarean delivery. Anesth Clin. 2016;35(1):P10724; Carvalho B, Butwick AJ. Postcesarean delivery analgesia. Best Pract Res Clin Anaesth. 2017;31:69-79 memungkinkan, 3) obat-obat dengan waktu paruh singkat, metabolit yang tidak aktif, dan memiliki riwayat penggunaan yang aman merupakan pilihan terbaik pada keadaan ini.

\section{Simpulan}

Karena prevalensi nyeri neuropatik pascabedah SS berupa alodinia dan hiperalgesia yang cukup tinggi, diperlukan skrining perioperatif dan faktor risiko mulai dari prabedah, intraoperatif, hingga pascabedah. Alat skrining Douleur Neuropathique en 4 (DN4) atau DN2 dapat digunakan untuk mencegah perkembangan menjadi nyeri persisten. Nyeri neuropatik akut dapat terjadi akibat cedera langsung pada saraf iliohipogastrika dan ilionguinal akibat pembedahan SS, yang selanjutnya memicu pelepasan ektopik dan perubahan kanal ion pada saraf perifer, serta memicu terjadinya sensitisasi sentral. Dengan demikian, pendekatan saat ini untuk pencegahan nyeri neuropatik kronis bertujuan untuk mengoptimalkan analgesia dan mengurangi nosisepsi dari nyeri akut dengan memodifikasi teknik bedah dan memilih anestesi regional. Pengobatan nyeri neuropatik memerlukan kombinasi terapi farmakologis, fisik, dan terapi perilaku. Beberapa terapi lini pertama pada penanganan nyeri neuropatik akut seperti gabapentinoid, opioid, antagonis reseptor NMDA, hingga terapi stimulasi listrik transkutan dan stimulasi medula spinalis menjadi pertimbangan untuk nyeri neuropatik akut.

\section{Daftar Pustaka}

1. Yogasakaran S, Menezes F. Acute neuropathic pain after surgery: Are we treating them early/ late?. Acute Pain. 2005;7 :145-9.

2. Macintyre PE, Schug SA. Chapter 12 Acute neuropathic and persistent postacute pain in Acute Pain Management A Practical Guide Fourth Edition. Taylor \& Francis Group, LLC. 2015. 187-97.

3. Sun KW, Pan PH. Persistent pain after cesarean delivery. International Journal of Obstetric Anesthesia.2019;40: 78-90. 
4. Niklasson B, Ohman SG, Segerdahl M, Blanck A. Risk factors for persistent pain and its influence on material wellbeing after cesarean section. Acta Obstet Gynecol Scand. 2015;94:622-8.

5. Pogatzki-Zahn EM, Segelcke D, Schugb SA. Postoperative pain from mechanisms to treatment. PR 9. 2017;2: 1-16.

6. Jain PN, Padole D, Baksh S. Prevalence of acute neuropathic pain after cancer surgery: A prospective study. Indian J Anaesth. 2015; 58:36-42

7. Laughlin RS et al. Postsurgical neuropathy: A descriptive review. Mayo Clin Proc. 2020;95(2):355-69.

8. Coutinho IC, Ramos de Amorim MM, Katz L, Bandeira de Ferraz AA. Uterine exteriorization compared with in situ repair at cesarean delivery: a randomized controlled trial. Obstet Gynecol 2008;111:639-47.

9. Searle RD. Acute neuropathic pain following surgery. Pain Med. 2013:1-232.

10. Costigan M, Scholz J, Woolf CJ. Neuropathic Pain: A Maladaptive Response of the Nervous System to Damage. Annu Rev Neurosci. 2009; 32: 1-32.

11. Baron R, Binder A, Wasner G. Neuropathic pain: diagnosis, pathophysiological mechanisms, and treatment. Lancet Neurol. 2010; 9: 807-19.

12. Fisher CJ, Yaksh TL, Bruno K, Eddinger KA. Basic Science of Pain: In Pangarkar S, Pham QG, Eapen BC, eds. Pain Care Essentials and Innovations. Cathleen Sether Publisher. 2020. 1-13.

13. Zhang J. The anatomy of postoperative pain in: Elliott JA, Smith HS, eds. Handbook of Acute Pain Management. Informa Healthcare. USA. 2016.1-8.
14. Weinstein EJ, Levene JL, Cohen MS, Andreae DA, Chao JY, Johnson M, Hall $\mathrm{CB}$, et al. Local anaesthetics and regional anaesthesia versus conventional analgesia for preventing persistent postoperative pain in adults and children. Cochrane Database Syst $\operatorname{Rev} 2018 ; 4$ (4).

15. Sng BL, Sia AT, Quek K, Woo D, Lim Y. Incidence and risk factors for chronic pain after caesarean section under spinal anaesthesia. Anaesth Intensive Care 2009;37:748-52.

16. Vijayan R, Jun K, Cardosa M, Ming K. Management of neuropathic pain 2nd Edition. UBM Medica. 2021. 1-30.

17. Takenaka S, Saeki A, Sukenaga N, Ueki R, Kariya N, Tatara T, Hirose M. Acute and chronic neuropathic pain profiles after video assisted thoracic surgery. Medicine. 2020; 99(13): 1-4.

18. Beloeil H, Sion B, Rousseau C, Albaladejo P, Raux M, Aubrun F, Martinez V. Early postoperative neuropathic pain assessed by the DN4 score predicts an increased risk of persistent postsurgical neuropathic pain. Eur J Anaesthesiol. 2017; 34:1-6

19. Artemiadis AK, Panagiotis Zis. Neuropathic Pain in Acute and Subacute Neuropathies: A Systematic Review. Pain Physician 2018; 21:111-20.

20. Schug SA, Palmer GM, ScottDA, Halliwell R, Trinca J. Acute pain management: Scientific Evidence Fourth Edition. Australian and New Zealand College of Anaesthetists. 2015. 282-3.

21. Gray P. Acute neuropathic pain: diagnosis and treatment. Current Opinion in Anaesthesiology 2008. 21:590-5

22. George RB, Carvalho B, Butwick A, Flood P. Postoperative analgesia. In: Chesnut DH, Wong CA, Tsen LC, Ngan Kee WD, Beilin Y, Mhyre JM, Bateman BT, editors. Chesnut's 
obstetric anesthesia, principles and practice, 6th Ed. Philadelphia: Elsevier; 2020. 627-56.

23. El Saied Hafiz MH, El Din Abdelhamid MH, Youssef MMI, Abdelrahim IKH. Randomized controlled trial of two oral regimens of gabapentin versus placebo in patients for Cesarean section under spinal anesthesia regarding postoperative pain, sedation, nausea, and vomiting. Egypt J Anaesth. 2017;33:59-65

24. Felder L, Saccone G, Scuotto S, Monks DT, Carvalho JCA, Zullo F, et al. Perioperative gabapentin and post cesarean pain control: a systematic review and meta-analysis of randomizeed controlled trials. Europ J Obstet Gynec Repro Bio. 2019;233:98-106.

25. Alaasar NM, Soud DEM, El-Deen AM, Elfattah IAA. Oral gabapentin versus pregabalin for postoperative pain relief in elective cesarean section patients under spinal anesthesia. Egypt J Hosp Med. 2020;81(1):1330-7.

26. Gupta S, Aggarwal A, Sharma R. Preemptive gabapentin vs pregabalin for acute postoperative pain in women undergoing cesarean section under spinal anesthesia: a prospective randomized double-blind study. Indian J Anesth Analg. 2019;6(5):1852-6.

27. El Kenany S, El Tahan MR. Effect of preoperative pregabalin on post-caesarean delivery analgesia: a dose response study.
2016;26:24-31.

28. Fabritius ML, Strom C, Koyuncu S, Jaeger P, Petersan PL, Geisler A, et al. Benefit and harm of pregabalin in acute pain treatment: a systematic review with meta-analyses and trial sequential analyses. Britis J Anaesth. 2017;119(4):775-91.

29. Moriyama K, Ohashi Y, Motoyasu A, Ando $\mathrm{T}$, Moriyama $\mathrm{K}$, Yorozu $\mathrm{T}$. Intrathecal administration of morphine decreases persistent pain after cesarean section: a prospective observational study. PLoS One 2016;11 e0155114.

30. Richebé P, Capdevila X, Rivat C. Persistent Postsurgical Pain Pathophysiology and Preventative Pharmacologic Considerations. Anesthesiology 2018; 129:590-607.

31. Fonseca PR, Gatto EO, Tondato VA. Posttrauma and postoperative painful neuropathy. Rev Dor. São Paulo. 2016;17(1):59-62

32. Bauchat JR, Higgins N, Wojciechowski KG, McCarthy RJ, Toledo P, Wong CA. Lowdose ketamine with multimodal postcesarean delivery analgesia: a randomized controlled trial. Int J Obstet Anesth 2011;20:3-9.

33. Sutton CD, Carvalho B. Optimal pain management after cesarean delivery. Anesth Clin. 2016;35(1):107-24. 